\title{
Diskursanalyse som metode til identificering af kollektive informationsbehov
}

\author{
Af Trine Schreiber
}

\begin{abstract}
Artiklens formål er at diskutere hvordan diskursanalysen kan anvendes som metode til identificering af kollektive informationsbehov. For det første ses der på Sanna Taljas arbejde med diskursanalysen med hensyn til både de teoretiske overvejelser om analysen generelt set og de mere fagspecifikke problemstillinger i relation til begrebet informationsbehov. Inspireret af Taljas arbejde foretages der for det andet en konkret diskursanalyse af et indsamlet materiale, der er hentet fra området af de mange aktuelle indsatser for etablering af netværk mellem videnskab og virksomheder. Analysematerialet består dels af en indspillet mødesamtale mellem nogle forskere og nogle virksomhedsfolk vedrørende indgåelse af en eventuel netværksaftale, og dels to udvalgte teoretiske tekster af henholdsvis Ulrich Beck og Helga Nowotny m.fl. Analysen af det teoretiske materiale bliver referencerammen for fortolkningen af det empiriske materiale. For det tredje gives der en konklusion på den konkrete anvendelse af diskursanalysen til identificering af kollektive informationsbehov på det beskrevne område. Analyseresultatet antyder, at der i debatten om netværksprojekterne eksisterer
\end{abstract}

nogle konflikter mellem de forskellige diskurser. Disse konflikter udtrykker kollektive informationsbehov. Ved identificering af disse informationsbehov er det vigtigt at erkende, at det er forskeren, der lægger denne specifikke begrebsmæssige vinkel ind i diskursanalysen og at forskeren herved selv er i gang med at anvende et bestemt fortolkningsmæssige repertoire.

\section{Indledning}

I de seneste årtier har især Tom Wilson (1981) og Robert Taylor (1991) præget vores forståelse af begrebet informationsbehov. Der har i de forgangne år været kritik af deres analysemodel. Alligevel har de inspireret til mange undersøgelser om brugernes informationsbehov (f.eks. Byström (1997); Hersberger (2001)). Wilson og Taylor lader begrebet om informationsbehov basere sig på bl.a. en psykologisk teori, hvor det, der er i fokus, er individets vidensmæssige udvikling. Men hvad nu hvis individets bevidsthed dårligt kan adskilles fra det sociale liv? Hvad nu hvis individet udvikler sine informationsbehov i kommunikationen med andre mennesker? I så fald vil vi have sværere ved at tale om det individuelle infor- 
mationsbehov. I stedet handler det måske om, at der i kommunikationen udvikles nogle kollektive informationsbehov? Det er netop dette spørgsmål, som i det følgende skal relateres til diskursanalysen.

Diskursanalyse er en analyse af kommunikation med det formål at bestemme den betydningsdannelse, som foregår gennem kommunikationen. I en diskursanalyse er det enkelte individ ikke analyseobjektet. Det er derimod betydningsdannelsen forstået som et kollektivt fænomen. Winther Jørgensen og Phillips har givet den velkendte definition af diskurs som "en bestemt måde at tale om og forstå verden (eller et udsnit af verden) på" (1999, s.9). Dette skal dog ikke forstås på den måde, at individernes måde at tale på afspejler deres omverden og de eksisterende sociale relationer. Individernes måde at tale på indtager derimod en aktiv rolle med henblik på at der foregår en konstruktion af en viden om omverdenen.

I de senere år er diskursanalysen blevet debatteret indenfor biblioteks- og informationsvidenskaben af bl.a. Sanna Talja fra Tampere Universitet i Finland. Hun har forsøgt at arbejde med analysen i relation til bl.a. emnet informationsbehov. I denne artikel er det hensigten at undersøge hvordan diskursanalysen kan anvendes til at identificere kollektive informationsbehov. Da Talja (1997,1999,2001a,2001b) har været inde på denne problematik, skal hendes forslag til en diskursanalyse gennemgås. Hendes forslag diskuteres ud fra følgende vinkler: Hvilken type af spørgsmål bliver relevante at stille sig, når man på baggrund af en diskursanalyse vil identificere de kollektive informationsbehov? Og hvad betyder det for vores forståelse af informationsbehov, at der anvendes en diskursanalytisk tilgang. Diskussionen af Taljas tekster bliver udgangspunktet for hvordan artiklens konkrete diskursanalyse efterfølgende udføres.

Dispositionen for artiklen er følgende: Der ses for det første nærmere på hvordan Sanna Talja har arbejdet med diskursanalysen og herunder specifikt hvilke erfaringer hun har erhvervet sig i forbindelse med anvendelsen af analysen til identificering af brugernes informationsbehov.
For det andet anvendes diskursanalysen på en empiri, som jeg har indsamlet i foråret 2003. Denne empiri handler om hvordan nogle forskere og private virksomheder forsøgte at etablere et netværk for en fælles produktudvikling. Der foretages en diskursanalyse af kommunikationen fra et bestemt møde mellem to af forskerne og nogle repræsentanter fra en virksomhed og det bliver diskuteret hvordan analysen identificerer kollektive informationsbehov i relation til et sådant møde mellem videnskab og praksis.

Endelig konkluderes der til sidst i artiklen på den anvendte metode og dens implikationer for fremtidige undersøgelser af informationsbehov.

\section{Sanna Taljas anvendelse af diskursanalysen}

I 1990'erne havde Sanna Talja sammen med nogle andre fået til opgave at skabe en netbaseret lokal informationstjeneste, nemlig 'The Digital Information Service of Tampere Region' i Finland. Projektet havde til formål at skabe en informationstjeneste, som havde et interface, der var baseret på brugernes måde at se tingene på. Derfor skulle de kommende brugeres informationsbehov og deres måde at tale om og udtrykke disse behov studeres. Informationstjenesten for Tampere regionen skulle bestå af mange forskellige typer af informationer. I artiklen af Talja m.fl. (1997) henvises der specifikt til opbygningen af en informationstjeneste for henholdsvis det lokale turistkontor, Tampere universitet, universitetsbiblioteket og et regionalt telefirma. Artiklen har dog først og fremmest præsentationen af diskursanalysen som sit omdrejningspunkt, hvorimod den endelige opbygning af regionens informationstjeneste kun får ganske sporadisk omtale. Det nævnes yderligere i artiklen, at arbejdet havde karakter af en pilotundersøgelse.

Diskursanalysen blev anvendt i projektet som en metode til at undersøge hvordan brugernes tilgang til bestemte emner, vidensområder eller typer af services var. Diskursanalysen var bygget op om følgende tre hovedspørgsmål (1997, s.117): 
1. Hvilke vinkler kendetegner brugernes tilgang til et bestemt emne?

2. Hvilke dimensioner organiserer brugernes informationsbehov?

3. Hvilke ord og fraser anvender brugerne?

Talja m.fl. (1997) konkluderer, at diskursanalysen har både fordele og begrænsninger. Hver af de fire undersøgelser har på den ene side givet forskerne en viden om dels brugernes ordvalg og dels de forskellige tilgange for brugen af ord. Anvendelsen af denne viden i forhold til opbygning af informationstjenesten har dog krævet yderligere tests og brugerevalueringer.

Analysemetoden opleves på den anden side at være meget arbejdsintensiv netop når man som $\mathrm{i}$ dette konkrete projekt skal afdække tilgange til mange forskellige emneområder. Det er forfatternes vurdering, at metoden især er anvendelig i forbindelse med opbygningen af en informationstjeneste, der skal dække et særskilt vidensområde eller en specifik, begrænset type af service.

Sanna Talja har siden 1997 skrevet både nogle artikler og en bog om brugen af diskursanalysen. I den refererede artikel (Talja m.fl.1997) samt i en anden artikel fra samme tid (Talja 1997) er hun først og fremmest inspireret af Michel Foucaults samt Stuart Halls teoretiske arbejde. Den sidstnævnte artikel har dog yderligere en reference til diskurspsykologerne Margaret Wetherell og Jonathan Potter. I hendes artikler samt bogen fra henholdsvis 1999 og 2001 indtager diskurspsykologiens repræsentanter Wetherell og Potter en central placering $i$ hendes teoretiske forståelse (Talja 1999; 2001a; 2001b).

I 1997 definerer hun diskurser som "knowledge formations", som ikke består af enkelte fragmenter af viden men af brede totaliteter, som giver virkeligheden en form (1997, s.117). Inspireret af bl.a. Stuart Hall beskriver hun videre samme sted en diskurs som en række ytringer, der giver et spro, en bestemt måde at tale om et særskilt emne på. En diskurs gør det muligt at tale om et emne på en bestemt måde, men samtidig indebærer den, at man begrænser sig fra at tale om samme emne på andre måder. I forhold til det nævnte er hun inspireret af Foucault med hensyn til at se på diskurser som noget forholdsvis regelbundet, der sætter grænser for hvad der giver mening. Hun udtrykker det f.eks. ved at sige at diskurser anlægger en bestemt vinkel på virkeligheden men vel at mærke også kun den ene vinkel, mens andre udelukkes.

Talja har dog ikke Foucaults opfattelse af, at man kan identificere ét vidensregime indenfor en bestemt historisk periode. I stedet indtager hun diskurspsykologiens antagelse om at der i hverdagen er tale om et konfliktfyldt billede, hvor forskellige diskurser eksisterer sideløbende og hvor det enkelte individ kan have svært ved at agere indenfor de diskurser, som andre tager for givne. I teksten fra 1997 taler hun således yderligere om diskurser som nogle "interpretative resources" eller perspektiver (Talja m.fl. 1997, s.117f). De fortolkningsmæssige ressourcer er alle de mange betydningsdannelser, der skabes henover tid i relation til hverdagens mange forskellige typer af praksis. Disse ressourcer er meget forskellige, ofte i indbyrdes konflikt og frem for alt altid under forandring. Ressourcerne er tilknyttet forskellige livsverdener og det er ikke altid let for individet at gå på tværs af de forskellige verdener.

Det er den sidstnævnte forståelse af diskurser, som Talja benytter sig af, når hun anvender diskursanalysen i forhold til biblioteks- og informationsvidenskaben. Hun anser at det centrale problem for denne videnskab netop er diskursernes forskellighed. Information, informationssystemer og informationsbehov konstrueres indenfor eksisterende diskurser. Individet vil derfor ikke være i stand til at begrebsliggøre sit informationsbehov eller ikke kunne formulere det på samme måde som producenten af informationssystemet, hvis han eller hun ikke har nogen tilknytning til den pågældende diskurs, som har været benyttet. Det er derfor altafgørende vigtigt for Talja, at informationssystemer er i stand til at inkorporere forskellige diskurser i systemet (Talja m.fl.1997, s.118f). 
I de senere artikler - som f.eks. Talja 1999, 2001a og 2001b - formuleres den diskurspsykologiske tilgang mere præcist. Diskurser oversættes nu med Wetherells og Potters udtryk "the interpretative repertoires" (Wetherell \& Potter 1988). Anvendelsen af det nævnte begreb slår fast, at hun i mindre grad ønsker den type af analyse, hvor man vil identificere den diskurs, som individerne trækker på i deres kommunikation og hvor man samtidig undersøger hvordan den identificerede diskurs konstruerer individernes identitet og har bestemte sociale konsekvenser. I stedet betoner hun den type af analyse, hvor man undersøger, hvordan diskurser bruges som fleksible ressourcer $\mathrm{i}$ individernes interaktion med hinanden. Her er individerne gennem deres samtaler givet en langt højere grad af mulighed for at skabe deres verden. Ved hjælp af en analyse af transskriberede samtaler om et bestemt emne finder man de forskellige fortolkningsmæssige repertoirer i relation til det pågældende emne. Dette gør man for at understrege, hvordan individerne $\mathrm{i}$ deres sociale interaktion er med til at skabe det pågældende emnes mulige tilgange og perspektiver.

Med brugen af begrebet fortolkningsmæssige repertoirer antydes det også, at hun er interesseret $i$ at se på en teksts eller tales retoriske organisering for herved at se på hvordan teksten eller talen er orienteret mod social handling. Individerne vil opnå noget med deres tale, dvs. alle har noget i spil og alle anlægger retoriske strategier, når de f.eks. indgår i en diskussion med andre om et bestemt emne. Analysen kan herved kaste lys på de måder, hvorpå individerne både er diskursive subjekter og agenter i såvel reproduktionen som forandringen af de sociale strukturer. Louise Phillips har beskrevet det på følgende måde: "Vi skal bruge - og er derfor begrænset af - de ord der eksisterer som ressourcer i vores tale, men vi bruger dem som fleksible ressourcer i argumentation og kan kombinere dem på nye måder og dermed bidrage til forandring" (Phillips 1999, s.115). I diskurspsykologien interesserer man sig vel at mærke ikke så meget for hvad folks holdninger egentlig er, eller folks motiver er til at sige hvad de siger, men deri- mod for hvordan holdninger konstrueres som argumenter i dialogiske processer.

I teksterne fra 2001 analyserer Talja et indsamlet interviewmateriale, hvor respondenterne (som er brugere af musikbiblioteker) er blevet udspurgt om deres forståelse af musikbiblioteker, deres materialer, udvælgelsesprincipper, deres relation til musiklivet generelt, m.m. Derudover har hun interviewet bibliotekarer om musikbibliotekernes mål og deres opfattelser af brugernes interesser. Endelig har hun indsamlet et tekstmateriale, der repræsenterer et bredere kulturpolitisk felt end lige bibliotekets. I dette materiale indgår officielle kulturpolitiske udmeldinger fra nationale råd, meddelelser fra radio- og TV-området, artikler fra musiktidsskrifter, dagspressens interviews med etablerede musikudøvere samt anmeldelser af musikbegivenheder.

En og samme respondent kan i sin tale udtrykke det, som analytikeren opfatter som modsætningsfyldt. I en diskursanalyse skal analytikeren opgive at forvente en sammenhængende gengivelse af respondentens handlinger og forestillinger. Taljas udgangspunkt er netop ud fra det indsamlede materiale at se forskelle og modsætninger i de præsenterede ytringer. Det er disse modsætninger, der giver ophav til at finde de forskellige fortolkningsmæssige repertoirer, der skabes i de dialogiske processer om pågældende emne.

I et interview indgår der ifølge Talja et fortolkningsarbejde fra respondentens side angående det emne, der spørges om. Når f.eks. brugerne skal tale om musikbiblioteket, producerer de ikke kun en neutral beskrivelse af biblioteket. De producerer en version af biblioteket og i denne version indgår der samtidig en evaluering heraf. Beskrivelse, evaluering og ikke mindst en reference til de eksisterende kulturelle modeller i forhold til emnet bliver i enhver tale knyttet tæt sammen. Meningsproduktionen i relation til musikbiblioteket vil aldrig foregå isoleret indenfor biblioteksområdet. Brugernes tale vil altid have intertekstuelle relationer til den øvrige tekstproduktion, der foregår i et bredere kulturpolitisk felt. Hendes inddragelse af tekstmaterialet bestående af offi- 
cielle kulturpolitiske udmeldinger m.m. indebærer en hjælp til at finde mønstre i respondenternes tale. Respondenternes anvendte diskurser svæver ikke frit i luften, men vil altid være forbundne med materielle og institutionelle sammenhænge.

Talja stiller analysen op i tre faser. I den første fase finder analytikeren nogle modsætningsfyldte udsagn $i$ forhold til et bestemt emne indenfor f.eks. et enkelt interview. I anden fase undersøges om de samme varierende syn på emnet findes $\mathrm{i}$ andre dele af materialet. Dette kan inspirere til at finde mønstre bag forskelligheden i måden hvorpå man beskriver, forklarer og argumenterer om emnet $\mathrm{i}$ de forskellige respondenters tale. Disse mønstre udgør mulige fortolkningsmæssige repertoirer. I analysens tredje og sidste fase identificeres de forskellige repertoires bagvedliggende antagelser og dermed opnås den endelige præcisering af særskilte måder at tale om det pågældende emne på (1999, s.466; 2001b, s.218).

Taljas analyse resulterer i opstillingen af tre fortolkningsmæssige repertoirer: For det første et generelt uddannelsesorienteret repertoire, hvor der udtrykkes en opfattelse af, at et musikbibliotek materialemæssigt skal indfri de uddannelsesmæssige krav. For det andet et alternativt repertoire, hvor opfattelsen er at materialerne skal udgøre et alternativ til det, mediernes musik almindeligvis byder på. For det tredje og sidste et efterspørgselsbestemt repertoire, hvor holdningen er, at det er den reelle efterspørgsel, der bestemmer bibliotekets indhold. Ved at inddrage både biblioteksudsagn og mere generelle kulturdiskussioner bliver det muligt for hende at synliggøre historiske måder at tale om og forstå biblioteksinstitutionen på.

Det er sådanne repertoirer, der kan siges at organisere informationsbehovene i betydningen at 'skabe' informationsbehovene. Identificeringen af de fortolkningsmæssige repertoirer er slutproduktet af en diskursanalyse og repertoiret er som sådan en navngiven diskurs (Talja 2001a, s. 11). I det følgende afsnit skal relationen mellem det fortolkningsmæssige repertoire og begrebet om informationsbehov tages op. For at komme ind på dette emne skal Taljas behandling af begrebet kontekst kort omtales.

\subsection{Kontekstforståelsen}

I 1999 publiceredes artiklen "The production of 'context' in information seeking research: a metatheoretical view". Talja er medforfatter hertil. Artiklen sammenligner to forståelser af kontekst, nemlig dels den objektiverende tilgang og dels den fortolkende tilgang. Den første angiver den forståelse af kontekst, som f.eks. netop traditionen omkring Wilson og Taylor repræsenterer, mens den anden indeholder et forslag til hvordan man i stedet skal forstå kontekst.

For den objektiverende tilgang er konteksten en uafhængig entitet, som har forskellig slags indvirkning på det objekt, som underkastes nærmere analyse. Konteksten er f.eks. ofte set som årsagen til at bestemte informationsbehov opstår. Wilson (1981) og Taylor (1991) anså, at individets informationsbehov var afhængigt af f.eks. organisationens strukturer, arbejdsopgaverne og tilgængelige informationskilder. Selvom disse typer af analyser har påpeget at informationsbehovet er betinget af omgivelsernes konkrete situation, har man alligevel haft til hensigt at forsøge at udlede generelle lovmæssigheder om adfærds- og dermed behovsmønstret. Det har været opfattelsen, at nogle objektive informationsbehov eksisterede 'derude' og ventede kun på at blive opdaget. Ideen var at finde dem ved hjælp af modellen over omgivelsernes indvirkning på individet samt en bestemmelse af individets adfærd. Derfor kaldes denne tilgang for 'objektiverende'.

For den fortolkende tilgang er konteksten ikke en uafhængig størrelse, men forstås derimod som noget, der er bærer af mening. En kontekst er f.eks. en diskurs, der dannes, reproduceres eller forandres i kommunikationen. En diskurs er ikke baggrunden eller årsagen til noget andet. En diskurs er et meningssystem, hvor en bestemt forståelse eller bestemt optik på et emne reproduceres eller forandres. I kommunikationen kan diskursen henvise til sig selv og den 
kan samtidig justeres og forandres alt efter hvorledes kommunikationen udvikler sig.

Den fortolkende tilgang indebærer en analyse af meningsskabende processer. Talja benytter derfor denne tilgang, når hun analyserer en kommunikation for dens fortolkningsmæssige repertoirer. Tilgangen kan ses som en metodologisk kollektivisme, hvor det er nogle fælles antagelser, værdier og holdninger, der sættes i fokus. Informationsbehovene er dermed ikke en effekt af nogle årsagsvariabler. De er derimod selv en del af diskursens (re)produktion.

\subsection{Begrebet informationsbehov}

Talja siger i en artikel, at informationsbehov er en social konstruktion bundet op til de respektive diskurser (Talja 1997, s.76; Tuominen; Talja \& Savolainen 2002). Hun siger ligeledes, at behovene er forbundet til de sociale handlinger (Talja 1997, s.78). Hvis man skal anvende den foregående teori til at forstå disse udsagn, så indebærer det, at vi skal forstå informationsbehov som en del af de meningsskabende processer. Det er i kommunikationen, hvor holdninger skabes, at også informationsbehovene konstrueres.

Der er dog endnu en ting der skal med, når vi siger 'informationsbehov' og som Talja efter min mening ikke tydeligt får præciseret. Et begreb som informationsbehov, der anvendes som en analysekategori, tilhører diskurser, der er udviklet indenfor en bestemt forskningsmæssig sammenhæng. Der er tale om forskernes valg og udvikling af en referenceramme. Når forskere sætter nogle begreber på det, de vil undersøge, er de således selv med til at skabe deres genstandsfelt. Når forskere derfor har fokus på emnet informationsbehov, så indebærer det, at de tvinger en bestemt kategori eller et bestemt begreb ned over de indsamlede data. Dette er præcis hvad der sker, når vi anvender en diskursanalyse til at identificere kollektive informationsbehov. Det er os selv som forskere, der har set en interesse $i$ at fortolke individernes kommunikation og meningsskabende processer i retning af det, vi selv forstår ved informationsbehov.
Som beskrevet ovenfor fandt Talja i sin undersøgelse af folks holdninger til musikbiblioteker tre fortolkningsmæssige repertoirer. På baggrund af den udviklede forståelse af informationsbehov vælger jeg at tolke eksistensen af disse tre repertoirer som en form for kollektivt informationsbehov. Sammenstødene mellem de tre repertoirer udtrykker hermed en række kollektive informationsbehov angående institutionen musikbiblioteket og den sociale praksis, der udspiller sig i sammenhæng hermed. Men med dette supplerende tolkningselement er det os som forskere, der har lagt et begreb oveni den første fortolkningsproces.

Det er først og fremmest fra vores egen biblioteksvin$\mathrm{kel}$, at repertoirerne rummer de kollektive informationsbehov. En undersøgelse af informationsbehovene er langt fra en undersøgelse af f.eks. søgeadfærden, som i Wilsons og Taylors tilgang til emnet. Der er derimod tale om for det første at analysere udsagn om et bestemt emne og vel at mærke udsagn, som ikke fastholdes som individuelle, men som på baggrund af et tekstmateriale kan argumenteres for at være intersubjektive eller kollektive. For det andet er der tale om, at vi udfra en biblioteksdiskurs har en intention om at forstå disse udsagn i relation til et begreb om de kollektive informationsbehov.

På den ene side har vi på baggrund af Taljas artikler og bog valgt at definere informationsbehov som tilhørende de meningsskabende processer, som individerne deltager i. Samtidig har vi på den anden side $\mathrm{i}$ forlængelse af hendes forståelse af begrebet kontekst bestemt begrebet informationsbehov som en del af en biblioteksdiskurs. Det er nødvendigt ved anvendelsen af diskursanalysen med henblik på at ville identificere informationsbehov at medtænke denne dobbelthed. Det er derfor endvidere nødvendigt under analysens gang at være i dialog med sit materiale angående denne dobbelthed. 


\section{Anvendelsen af diskursanalysen på et net- værksprojekt}

\subsection{Metode}

Vi skal i det følgende anvende diskursanalysen på en empiri indsamlet $i$ foråret 2003. Det er intentionen med denne analyse at identificere kollektive informationsbehov i forbindelse med etableringen af samarbejdsprojekter mellem forskningsinstitutioner og private virksomheder om udvikling af nye produkter. Denne type af projekter har i de seneste år fået økonomisk støtte stillet i udsigt fra statens side, og en del bevågenhed fra mediernes side. Denne type af samarbejdsprojekter er blevet kaldt netværksetablering.

I januar 2003 blev der etableret en sådan type af samarbejde. Det konkrete projekt blev indledningsvist initieret af nogle offentlige institutioner, nemlig et forskningscenter ved en dansk uddannelsesinstitution, to uddannelsesbiblioteker samt institut for biblioteksudvikling ved Danmarks Biblioteksskole. Formålet var at udvikle et vidensnetværk bestående af folk fra forskning, erhvervsliv og uddannelse. Ved hjælp af et sådant netværk skulle der iværksættes en produktudvikling. Ideen var, at forskernes viden skulle spredes til virksomheder og herved give ophav til, at disse kunne drage nytte af denne viden og selv bidrage med egen viden som en form for respons, samt ikke mindst også at investere en vis økonomisk kapital i projektet. Forskerne havde på sin side mulighed for at få økonomisk støtte fra en statslig pulje kaldet IT-korridoren. Sammen skulle man på denne måde søsætte nye typer af produktudviklinger. Jeg deltog i projektet med det formål at undersøge hvordan en sådan netværksetablering kunne støttes fra et biblioteks side. Med denne sidstnævnte vinkel blev det centralt at identificere de kollektive informationsbehov. Undersøgelsen forløb fra 1. januar 2003 til 1. juli 2003 og modtog ekstern økonomisk støtte.

Diskursanalysen i det følgende benytter sig af to typer materiale. For det første anvendes empirien fra det beskrevne konkrete samarbejdsprojekt mellem forskning og praksis. Dette materiale består bl.a. af en indspillet samtale mellem forskere og virksomhedsrepræsentanter ved et møde, som var arrangeret for at muliggøre en samarbejdsaftale mellem de to parter. Denne samtale bliver i det følgende analyseret.

For det andet trækker analysen på et tekstmateriale bestående af to værker, som har haft en stor gennemslagskraft i samtidens diskussioner om hvad videnskaben betyder for samfundets udvikling. De to værker er Ulrich Becks "Risikosamfundet" (1997/ publiceret første gang i 1986) og Helga Nowotny m.fl. "Re-thinking Science" (2001). Dette materiale giver et grundlag for at analysere det nævnte møde og de anvendte fortolkningsmæssige repertoirer. Det konkrete møde er for begrænset en situation til at kunne blive analyseret for sig selv. Ved at inddrage en analyse af de to nævnte værker får man et fundament til at definere og navngive mødets anvendte repertoirer. Man kan til og med argumentere for en materiel og institutionel forankring af den eller de diskurser, som disse bøger er en del af, idet der i de sidste par år f.eks. er blevet etableret fonde til støtte for netværksetableringer, arrangeret agora' er i regi af f.eks. Learning Lab Denmark, og igangsat en såkaldt Tech Trans Enhed under København Universitet.

Analysen følger på flere måder Taljas forståelse af diskursanalysen. Den er inspireret af diskurspsykologien med henblik på at undersøge hvordan individerne anvender de forhåndenværende diskurser eller fortolkningsmæssige repertoirer på en strategisk måde til at fremstille sig selv og andre på bestemte måder i den sociale interaktion. Den anvender sig dog ikke af denne tilgangs fokus på specifikt ordvalget $\mathrm{i}$ kommunikationen. Det kunne også have været inddraget, men er blevet fravalgt i det konkrete tilfælde. Analysen understreger individernes aktive brug af de fortolkningsmæssige repertoirer, og udleder heraf hvilke konsekvenser dette kan have for muligheden for at etablere et netværk mellem forskere og virksomhedsfolk og herunder hvilke kollektive informationsbehov, der er aktuelle i den forbindelse. 
I det følgende skal først de nævnte to teoretiske værker diskuteres. Dernæst skal mødets kommunikation analyseres.

\subsection{Diskurser omkring videnskaben}

Diskursanalysen trækker som sagt på to teorier om hvad videnskaben betyder for samfundets udvikling. Den ene, Ulrich Becks, beskriver samfundet som et risikosamfund. På den ene side føler folk sig i dag afhængige af videnskabelig viden og 'rationalitet' på grund af de samfundsskabte risici. Samtidig er folks tillid til videnskaben mindsket. Den videnskabelige rationalitet er $\mathrm{i}$ forbindelse med denne tillidskrise $\mathrm{i}$ stigende grad blevet udfordret af en såkaldt social rationalitet, der henter sine argumenter fra hverdagslivet.

Den anden teori udviklet af Nowotny m.fl. (2001), står for en opfattelse der blander Becks forståelse med en mere optimistisk version af videnssamfundet. Et samarbejde mellem videnskab og teknologi kan betyde en produktivitetsøgning i samfundet. Den relevante viden er dog både videnskab og den form for problemløsning, der dagligt foregår på praksisniveauet i virksomhederne. Vidensproduktionen, som er deres udtryk for forskningen, foregår ikke længere kun indenfor universitetet eller de traditionelle forskningsinstitutioner, men derimod på baggrund af tværorganisatoriske samarbejdsrelationer. Bogen anvender udtrykket "kontekstualisering af viden". Dette betyder, at samfundet $i$ dag giver sin respons på de oplæg, der kommer fra videnskabens side. Forfatterne benytter også udtrykket "the context speak back" for denne proces (2001, s.50). Jo stærkere kontekstualiseret viden er, jo mere anser forfatterne den for at være "social robust" (2001, s.64 og s.167). Robustheden produceres ved, at forskningen blandes og fornyes med den sociale videns interesser og forståelser.

Begge teorier har et særligt fokus på en slags lokal viden forstået som henholdsvis virksomheders, lokale gruppers og individers viden. For opfattelsen i
Nowotny m.fl. (2001) bliver betoningen af den lokale viden en udvidelse af videnbegrebet, mens det for Becks opfattelse snarere handler om at stille sig i opposition til videnskabens påståede universalitet og dermed til dens magtfulde position.

Med Becks teori kan man spørge om der i dag i samfundet er en orientering i retning af at ville erstatte den videnskabelige rationalitet med en social rationalitet? Eksisterer der denne kamp imellem den videnskabelige diskurs og en social rationalitet? Hans teori medfører også spørgsmålet om hvad denne sociale rationalitet nærmere består af? Er det en rationalitet, der har samfundets vel på sinde eller er den kendetegnet af private interesser, hvor det først og fremmest er organisationens eller individets egen hverdag, der kendetegner holdningen?

Med teorien fra Notwotny m.fl. kan man spørge om hvad indholdet vil være af en rationalitet, der baserer sig på en netværksforståelse. Et netværk skal som sagt kontekstualisere viden på en social robust måde, d.v.s. på en måde som ikke er kendetegnet af private interesser; men hvad er den så kendetegnet af? Deres teori lægger op til spørgsmålet om en sådan netværksrationalitet er i gang med at blive konstrueret $\mathrm{i}$ forbindelse med de allerede etablerede samarbejdsprojekter mellem forskning og praksis? Samt hvad en sådan netværksrationalitet da består i?

I forlængelse af begge tekster kan man forestille sig forskellige diskurser og deres indbyrdes kampe om hvad der er sandt og usandt. Situationen kan i forlængelse af Becks teori være præget af et sammenstød mellem en videnskabelig diskurs og en praksisdiskurs, hvor hver af de to ønsker af definere hvad viden og rationalitet er. De to teorier giver ikke bud på hvad den sidste, praksisdiskursen, eventuelt kan bestå af. Den kan måske indikere flere diskurser, som hver er oppe imod hinanden. Det er vanskeligt at bedømme hvad indholdet af Becks social rationalitets diskurs er. Den kan være i overensstemmelse med virksomheders praksisdiskurser og den kan være forskellig herfra. Notwotny m.fl. (2001) udtrykker en netværksdiskurs, hvor det antages at deltagerne 
i netværket sammen i det konkrete tilfælde definerer hvad rationalitet er. Måske er den sociale rationalitet $\mathrm{i}$ visse tilfælde ensbetydende med denne netværksdiskurs? Måske har den videnskabelige diskurs forskubbet sig over til denne netværksdiskurs? Eller måske har netværksdiskursen ikke fået et indhold endnu. Det nævnte er alle spørgsmål, som tages med $i$ analysen af den konkrete mødesamtale.

I det følgende analyseres det konkrete møde. I forbindelse med dette møde er det oplagt at spørge om hvilke tilgange de respektive parter havde til mødets emne forstået som netværksetableringen. Det er interessant at spørge om hvilke fortolkningsmæssige repertoirer og - i næste trin - hvilke kollektive informationsbehov, der konstrueres i kommunikationen.

\subsection{Det konkrete møde}

Mødets kommunikation analyseres nedenfor ved anvendelse af den diskurspsykologiske teori. Ved gennemgangen af mødets kommunikation ses der på den retoriske organisering i f.eks. virksomhedsfolkenes tale, dvs. der ses på hvilke repertoirer, de anvender i argumentationen for enten at ville deltage i netværket eller ikke ville deltage. De kan eventuelt tænkes at kombinere nogle velkendte repertoirer på nye måder og derved bidrage til forandring. Individerne trækker som ovenfor nævnt ikke passivt på diskurserne, men de gør det selektivt, man forandrer dem og udfordrer dem. Holdningerne skabes og konstrueres således gennem de dialogiske processer.

De holdninger, som bliver analysens resultat, skal tolkes i retning af nogle kollektive informationsbehov. Ved et eventuelt sammenstød mellem videnskabelig diskurs og praksisdiskursen indikeres at de to parter behøver mere information om hinanden. Forskere behøver at vide noget om virksomhedsverdenen og virksomhederne behøver at vide noget om forskerverdenen, dvs. der er her tale om to forskellige informationsbehov. Hvis analysen viser et sådant informationsbehov, antyder den at en etablering af et netværk ikke umiddelbar er nogen nem opgave. Omvendt kan analysen måske vise, at parterne gennem kommunikationen konstruerer nogle fælles informationsbehov, der ikke på denne måde placerer dem i hver sin bås. En sådan konstruktion af nogle fælles behov kan indikere, at et netværk eventuelt kan etableres i fremtiden.

Mødets deltagere var to forskere, to repræsentanter fra en privat virksomhed, en repræsentant fra en uddannelsesinstitution samt tre personer, som skulle observere mødets gang og rådgive om udformningen af fremtidige møder. Jeg var selv en af de tre observationsdeltagere. Mødet havde en varighed på et par timer og blev indspillet på bånd.

Netværksetableringen var indledningsvist baseret på to forskningsmæssige emner kaldet case 1 og case 2 . I case 1 havde forskerne en viden om indhold og struktur til en engelsksproglig, fagrelateret database, og i case 2 havde de en viden om nogle elementer til et e-lærings software. Forskerne præsenterede først case 1 og siden case 2 for de to folk fra virksomheden. Forskerne ville gerne som resultat af deres præsentation opnå en tilkendegivelse af en interesse fra virksomhedens side til at gå ind og være med vidensmæssigt og økonomisk i et netværk omkring en produktudvikling.

I det følgende er Frank og Finn de to forskere, mens Vagn og Vinter er de to folk fra virksomheden. Mødet starter med, at Frank præsenterer netværksideen. Han beskriver netværket som det at "koble forskelligheder til et fælles projekt".

Herefter præsenterer han emnet i case 1 . Han beskriver, at det handler om at skabe en fælles database over definitioner af fagudtryk indenfor et bestemt fagområde. Alle virksomheder indenfor faget kan bidrage med den mængde af fagudtryk eller ord, som de anvender i hverdagen. Hver gang en ny virksomhed melder sig i netværket, vil fællesmængden af ord stige.

Folkene fra virksomheden begynder at stille spørgsmål til case 1 . Som vist i følgende ordudveksling stiller de et spørgsmål til forskerne, som disse vanske- 
ligt kan svare på, men som ikke desto mindre synes meget relevant. Forskerne viser i hvert fald deres interesse i at få besvaret spørgsmålet.

Vagn: Er de ord I søger kun anvendelig for ingeniørsnak eller er de rettet til almindelige folk?

Frank: Vi har et problem der. Indtil videre er basen rettet mod alle. Måske kan vi på et tidspunkt indføre en opdeling. Men der er endnu ingen krav om det. Man kan forestille sig, at der ved hver definition gives en anmoerkning om det.

Vinter: Der er jo meget stor forskel på redigeringskrav med hensyn til om det er det ene eller andet.

Frank: Der kan loegges forskellige kriterier ind.

Finn: Det må vaere et spørgsmål om at tilføre det noget ekstra. Det må vel vare vores arbejde.

Frank: Det skal altid passere en såkaldt informant, d.v.s. en specialuddannet, som gør et virkelighedstjek på termerne. Her skulle vi lave en slags redaktionskomite.

På baggrund af virksomhedsfolkenes spørgsmål opstår der hermed indledningsvist en situation, hvor dialogen er i gang med at skabe et fælles informationsbehov. Det nævnte vil være et fælles informationsbehov i det øjeblik, der etableres en fælles aftale om et netværk. I denne kommunikation er der tiltag til en netværksdiskurs, hvor man sammen skal skabe indholdet i en netværksaftale med henblik på vedligeholdelse af det nye fælles produkt, kvalitetskontrol m.m.

De to fra virksomheden går videre $\mathrm{i}$ deres tale med at være produkt- og udviklingsorienteret. Forskerne forsøger omvendt at vise, at de har tænkt over indtjeningssiden, dvs de anvender sig af et fortolkningsmæssigt repertoire, som de kunne forvente sig virksomhedens folk ellers vil spille ud med. Parterne synes på denne måde indledningsvist at ville gå ind i mødets dialog på den anden parts vilkår. Dialogen viser også, at begge parter har et fælles informationsbehov med hensyn til den fremtidige økonomi i forbindelse med en eventuel fælles produktudvikling. Igen er der tiltag til en fælles netværksdiskurs.
Vagn: Når forsøgsudviklings-perioden er ovre, hvad så? Der må vare nogle serviceopgaver og-udvikling $i$ det her?

Frank: Jo, jeg har netop toenkt på, at det skal jo munde ud $i$ et forretningsmoessigt produkt. En cd-rom måske? Man kan så forestille sig, at folk kan købe en licens til termbasen. Der er i hvert fald ingen tvivl om, at jo flere institutioner, der er med, jo større vardi er der $i$ det. Der er helt sikkert en besparelse $i$ at gå sammen om at udvikle det. Jeg ved ikke hvad en sådan licens kan toenkes at koste, en $3000 \mathrm{kr}$ ?..... Hovedprojektet er toenkt at løbe over en 3 år, så må vi se om der er en forretning i det, om det kan aflønne de folk, der fremover så skal tjekke basens indhold.

Økonomien synes som vist at være en anelse usikker. De to fra virksomheden går dog ikke nærmere ind i emnet. I stedet begynder de at beskrive deres organisation nærmere. De fortæller bl.a. om hvordan dagligdagen struktureres, deres opgavevaretagelse og herunder f.eks. at de ikke har deres anvendte fagudtryk eller ord defineret i skriftlig form. Måske har de på dette tidspunkt vurderet at de alligevel ikke vil være med eller også er de oprigtig interesserede $i$ at få hjælp til at forstå hvordan de kan være med. I deres beskrivelse af problemerne kan man sige, at de forsøger at konstruere en diskurs om hvem de selv er.

Vagn (til Vinter): Du har nok ret $i$, at vi har meget tavs viden. Vi bruger ikke energi på at skrive det ned.

En repræsentant fra uddannelsesinstitutionen: Men når I oplaerer folk, skal I jo bruge nogle ord.

Vinter: Men vi vagter meget den personlige kontakt $i$ vores virksomhed. Vi spørger hinanden om hvem det er, vi skal have fat $i$, hvis vi skal vide noget mere ... end at vi satser på skoermen.

Vagn: Det vil betyde en kompe adfcerdscendring, hvis vi skal gå ind $i$ det her. Vi skal jo først til at bygge en sådan base op.

Finn: Stiller I jer aldrig spørgsmålet: Hvordan skal vi forstå det og det ord?

Vinter: Nej, jeg tror at mange af vores ansatte ikke vil voere interesseret $i$ det her. Måske vil en af vores 
ildsjoele vare det, nemlig blandt dem der arbejder med relationen til brugerne. Eller $i$ betjeningsvejledningen. Men vores succes kriterium er ikke formidling.

Virksomheden forsøger således at beskrive for forskerne, at de har en arbejdskultur, der ikke lige umiddelbart synes at være $\mathrm{i}$ overensstemmelse med forskernes præsenterede emne. I denne beskrivelse lader de fremstå, at de er en uformel organisation med megen personlig kontakt, hvilket måske er et forsøg på at sætte sig selv i et positivt lys overfor mødets deltagere. De anvender sig af en praksisdiskurs. Hvis vi skal kalde denne praksisdiskurs for en social rationalitets diskurs i retning af den, som Ulrich Beck taler om i sin bog, så indikerer begrebet social rationalitet, at det er de allerede etablerede hverdagsprocedurer, der afgør hvad der er rigtigt og hvad der er forkert.

Henvisningen til virksomhedens arbejdskultur fremstår som et argument for ikke at være med i netværksprojektet. Man kan sige, at reelt har forskerne her et informationsbehov hvad angår hvilken type af virksomhed de sidder og taler med. Forskerne forsøger da også i det ovenfor beskrevne citat at gå ind med et spørgsmål til virksomheden for at lære den nærmere at kende og eventuelt herved finde argumenter for deres deltagelse i projektet. Dette gør de dog indenfor rammerne af hvad vi kan kalde en videnskabelig diskurs. De siger nemlig som vist: "Stiller I jer aldrig spørgsmålet: Hvordan skal vi forstå det og det ord?" Spørgsmålet synes at stille virksomheden i en forsvarsposition. I hvert fald afvises det af virksomhedsfolkene i det nævnte citats sidste bemærkning: "Nej, jeg tror at mange af vores ansatte ikke vil være interesserede i det her". Her er de tilbage i diskursen om dem selv, hvor de på en selvrefererende måde taler om deres ansattes interesser.

Dette gentager sig i det videre forløb. I det nedenstående citat formulerer en af virksomhedsfolkene igen en afstandstagen til en videnskabelig diskurs. Han siger nemlig, at de ikke behøver noget "abstrakt" viden. Han anlægger i stedet en pragmatisk eller en slags nyttighedsdiskurs. De anser, at de har brug for det, der er nyttigt for virksomheden.

Vagn: En definitionsorienteret base på dansk, det vil jeg måske vare interesseret $i$. Det kan jeg måske finde ud af. Men en engelsk,... det bliver for abstrakt for mig. Noget engelsk har vi, når vi f.eks. skriver artikler.

Vinter: Vi har ikke 500 ord på engelsk.

Det synes dog stadig som om, at de er interesserede $\mathrm{i}$ projektet. De spørger nemlig forskerne om, hvad der kunne tænkes at motivere deres ansatte til at være med. Forskerne forsøger at slå et slag for at kunne besvare spørgsmålet. Virksomheden går ganske kort ind på deres forslag, men vender dog straks tilbage til spørgsmålet om hvad deres ansatte vil.

Vagn: Men hvordan får vi folk motiveret til det her? Frank: Det, der skal scelge det, det er jo at man skal skrive noget.

Vinter: Vi skriver manualer - der kunne måske vare noget der? Spørgsmålet er om de folk der skriver manualerne kan se noget $i$ det her.

Igennem talen har virksomhedsfolkene mere og mere sat et praksis-repertoire i spil, som vi kan kalde en arbejdsdemokrati-diskurs. Det er således deres ansatte, der synes at skulle bestemme om de skal være med eller ej.

Forskerne viser herefter i det følgende udpluk af dialogen, at de i deres verden har så stor en autonomi og fleksibilitet, at de umiddelbart kan gå ind og ændre på projektets plan og ide. De viser dette ved at sige, at projektet da kan indoptage virksomhedsfolkenes ønske om at dansk betydning lægges ind i basen. De bruger det uden tvivl for at forbedre chancerne for at få virksomheden med i netværket. Virksomheden fastholder dog på deres side, at de har deres egne ansatte at tage hensyn til. Derudover lægger de i det følgende samtalecitat yderligere et modargument på bordet, nemlig henvisningen til IT-branchens overophedning. De placerer nemlig forskernes tilbudte 
viden blandt den mængde af IT-firmaer, som falbyder sig for tiden.

Finn: Vi kan jo sige at der på sigt også skal logges dansk betydning ind

Vinter: Det her må vi gå hjem og snakke med folk om. Det kan vi ikke tvinge igennem.

Vagn: Det er noget vi kan have interesse i. Det er der ikke tvivl om, men IT-tiltag er der forlods skepsis til. De kommer jo i stride strømme. Firmaer falbyder jo deres IT-produkter.

Frank præsenterer herefter emnet for case 2 ved hjælp af en power point præsentation. Der er tale om et elearnings software, der behøver at videreudvikles. Frank viser konkret hvordan softwaren kan bruges.

$\mathrm{Nu}$ synes virksomheden interesseret $\mathrm{i}$ kontant at indkøbe en ydelse fra forskerne. De vælger her til sidst igen at anvende nyttighedsdiskursen i kommunikationen. Forskerne forsøger dog heroverfor at holde projekt- og netværksideen i hævd:

Vagn: Vi kan have gavn af en eller anden censurering, når vi skriver en artikel. Når vi satter en til det, så er jeg sikker på, at han kan gøre brug af en sådan struktur. Kan vi etablere sådan en censurering, sådan en service, så er det genialt. Men hvad krcever det?

Frank: ....

Vagn: Hvad skal man yde?

Frank: Man skal yde nogle tekster og man skal frikøbe de mennesker, der skal analysere teksterne, fra deres andre forpligtelser. Hvilket dog kan trcekkes fra. Jeg har set $i$ et cirkuloere fra videnskabsministeriet at den investering giver et fradrag af en vis størrelse.

Vagn: Jeg skal lige have det en gang til. Vi siger, at vi har lavet en tekst .. til f.eks. et tidsskrift. Hvad gør vi så?

Frank: Så er der en af centrets medarbejdere, der laser korrektur på teksten - for en bestemt timeløn.

Vinter: Det er simpel outsourcing. Hvis vi kan købe sådan en service, så vil det vare fint.
Vagn: I skal toenke forretning i det her: Hvis I ikke har gjort det, så skal I gøre det.

Frank: Nu kommer vi fra universitetet - vi tænker ideerne ud.

Mødet er som vist endt op i en tydelig modsætning mellem virksomhedens forretningsmæssige diskurs og forskernes intellektuelle diskurs, altså en kamp mellem det vi indledningsvist kaldte for den videnskabelige diskurs og en form for en praksisdiskurs.

Mødet blev som beskrevet indledt med at parterne tog udgangspunkt i det, som de anså var modpartens verden, men gennem dialogen ender de, som vist, $\mathrm{i}$ konstruktionen af en type diskurser, som i samfundet ofte tilskrives de respektive parter. De repertoirer, der organiserer de kollektive informationsbehov, har med andre ord en tendens til at blive en reproduktion af de allerede eksisterende billeder af de to parter. Man kommer i sidste instans ikke til at udfordre og forandre de i samfundet eksisterende diskurser. Udsagnene udtrykker i sidste instans det, som vi ud fra Becks teori fortolkede som et sammenstød mellem den videnskabelige diskurs og en praksisdiskurs. Den sidste, praksisdiskursen, fremtræder dog ikke i udsagnene som et entydigt alternativ til den videnskabelige rationalitet, d.v.s. hvis vi beskriver den ved et begreb som social rationalitet, får vi ikke noget klart indtryk af hvad denne mere præcis kan bestå $i$. Det, der i praksis afgør hvad der er rigtigt eller forkert, svinger fra at være de allerede etablerede hverdagsprocedurer til at være det nyttige eller det, som de ansatte vil være med til.

Reproduktionen af de nævnte diskurser styrker ikke en netværksetablering. Tonen i mødet er til slut høflig - som vist i citatet nedenfor - hvilket indebærer, at man på den anden side heller ikke kan tale om, at der eksisterer en tydelig afstandstagen til en sådan etablering.

En repræsentant fra uddannelsesinstitutionen (henvendt til virksomheden): Bolden ligger stadig ovre hos jer 
Vagn: Jeg skal hjem og tale om det. Det sidste ... er noget vi måske kan bruge.

En repræsentant fra uddannelsesinstitutionen: Har I bud på hvornår I har en tilbagemelding?

Frank: Det er vigtigt for os, at det er indenfor en god måneds tid.

Vagn: Vi vil gerne have på skrift hvad det kræver af os i hovedprojektet. Hvilke ydelser det kræver.

Vinter: Samt også hvilke nydelser der ligger heri for os.

I de første kommentarer til mødet blev det nævnt, at parterne kunne have et fælles informationsbehov med hensyn til dels projektets fremtidige indhold og dels den fremtidige økonomi i forbindelse med en eventuel netværksetablering. Havde parterne nærmet sig hinanden i forhold til en netværksetablering, havde det måske kunnet tolkes som dialogens konstruktion af en ny type af diskurs og dermed en ny type af informationsbehov. I stedet synes som nævnt de allerede eksisterende behov at blive reproduceret gennem mødets kommunikation.

Igennem samtalen mellem to parter anvendes der som vist flere typer af fortolkningsmæssige repertoirer. Fra virksomhedens side er man tidligt i samtalen i gang med at konstruere en diskurs om sig selv, som er tæt knyttet sammen med en nyttighedsdiskurs og den omtalte arbejdsdemokrati-diskurs. Folkene herfra lader indirekte forstå, at de savner en indsigt fra modpartens side i deres form for organisation og arbejdskultur. De savner også information om hvordan de bedre kan motivere deres ansatte til at interessere sig for den pågældende type af viden. Forskerne lader dog som vist i stedet en videnskabelig diskurs træde frem. De oplever omvendt, at virksomhedens folk har svært ved at gå ind på en reel diskussion om deres viden, som de tilbyder gennem præsentation af de to cases. De kan eventuelt opfatte deres egne repertoirer som udtryk for en ny netværksdiskurs. Deres kommunikation bekræfter dog, at parterne savner information om hinanden.

Eksemplet viser hvordan diskursanalysen kan anvendes til en identificering af informationsbehov. I eksemplet viser diskursanalysen hvordan de kollektive informationsbehov gennem kommunikationen bliver kendetegnet ved sammenstødet mellem de traditionelle syn på de to verdener, virksomhedens og forskningsverdenen.

Den nævnte analyse har dog ikke bevist, at sammenstødet mellem den videnskabelige diskurs og praksisdiskursen dominerer i dagens samfund. Analyseeksemplet kan kun antyde, at disse to diskurser rekonstrueres som fortolkningsmæssige repertoirer i dialogiske processer mellem parterne. Set i et samfundsperspektiv er sammenstødet mellem diskurserne udtryk for, at der trods mange netværksforsøg stadig kan eksistere et kollektivt informationsbehov med hensyn til hvordan en netværksetablering er mulig, hvad en eventuel social rationalitet kan bestå i, hvordan en sådan kan understøtte en udvikling af en fælles viden (eventuelt kaldet 'social robust' viden, jævnfør Nowotny m.fl. (2001)) samt hvordan forskerverdenen kan komme nye interesser i møde.

I eksemplet kunne vi have stoppet vores analyse ved konstateringen af hvilke repertoirer parterne konstruerede $\mathrm{i}$ dialogen $\mathrm{i}$ forhold til at være interesserede $\mathrm{i}$ at indgå i et netværk eller ej. Som vist supplerede vi analysen ved også at tale om kollektive informationsbehov i relation til diskurserne. Dette supplement bygger selvfølgelig på vores biblioteksinspirerede interesse $i$ at identificere informationsbehov. Med en dialog med os selv og vores anvendte begreber kan diskursanalysen identificere kollektive informationsbehov. Vi er gået ind og har tolket nogle dialogiske processer, først i form af nogle diskurser, og sidenhen $\mathrm{i}$ form af nogle informationsbehov. På denne måde udgør spørgsmålet om informationsbehovene et efterfølgende fortolkningstrin i forhold til analysens diskursfortolkninger.

\section{Konklusion}

Der skal kort gives en konklusion med hensyn til diskursanalysens konkrete anvendelse i retning af at identificere kollektive informationsbehov. 
Sanna Taljas anvendelse af diskursanalysen blev ovenfor refereret. Hun anbefalede brugen af tre analysefaser. I anvendelsen af diskursanalysen på det indsamlede materiale om mødet mellem videnskab og praksis anvendtes dog ikke disse faser. Derimod blev et andet råd fra Talja anvendt. Hun anbefalede at et konkret interviewmateriale om f.eks. holdninger til biblioteksinstitutionen blev udvidet med et bredere tekstmateriale fra det kulturpolitiske felt. Dette var efter hendes mening centralt for at kunne argumentere for anvendelsen af fortolkningsmæssige repertoirer i den konkrete kommunikation. Analysen af mødet mellem videnskab og praksis efterkom dette råd ved at udvide empirien med et tekstmateriale bestående af to teoretiske bøger, der i de seneste år har haft en del omtale i forskellige typer af medier. Dette materiale indebar at analysen af mødet fik et fundament $i$ en debat, som præger samfundet $i$ dag. Man kan dog kritisere om det udvalgte materiale var tilstrækkeligt, d.v.s. om det i tilstrækkelig grad kunne påvise nogle centrale mønstre i det sociale domæne, som de aktuelle forsøg på at etablere netværk rundt om i samfundet er en del af. På dette område kunne man klart med fordel underbygge analysen yderligere.

Den konkrete analyse af mødet mellem forskere og virksomhedsfolkene gav som resultat en identificering af nogle kollektive informationsbehov. Disse behov var karakteriseret ved spørgsmålene om hvordan en netværksetablering mellem de to parter var mulig, når der stadigvæk kommunikeres ud fra hver sin diskurs, hvad en praksisdiskurs eller en social rationalitet kunne bestå i, hvis den skulle indgå som forudsætning for et partnerskab med forskerne samt hvordan den videnskabelige diskurs kunne udvikles, hvis den skulle imødekomme nogle nye krav fra samfundet. Der er ikke hermed givet svar på spørgsmålene. Det er derimod blevet vist, at disse spørgsmål er vigtige at få debatteret og dermed givet et indhold gennem en debat. Det kollektive informationsbehov bliver på denne måde et kommunikationsbehov, hvor der på baggrund af en bred debat bliver arbejdet med at bedømme forudsætningerne samt indholdsbestem- me kriterierne for de omtalte netværksetableringers virke.

Informationsbehovet er således på baggrund af en diskursanalyse ikke et spørgsmål om hvilke kildetyper og informationsressourcer, der især kan behøves. Det er heller ikke et spørgsmål om at få undersøgt informationsbehovet ved at afdække individers søgeadfærd. Der er derimod blevet tale om nogle behov, som opstår på baggrund af konflikter mellem forskellige diskurser og som ikke kan undersøges ved et fokus på individet, men som forudsætter en analyse af et sammenstød mellem forskellige måder at tale om og forstå f.eks. netværksetableringerne på. Vi kan hermed tale om en metodologisk kollektivisme i stedet for en metodologisk individualisme.

I diskursanalysen afdækker forskeren antagelser, værdier og holdninger på tværs af individernes udsagn. Som vist i afsnittet om eksemplificeringen er det op til forskeren at vælge at supplere analysen med en anvendelse af analysekategorien informationsbehov. Det er et udtryk for en biblioteks- og informationsvidenskabelig vinkel på den indsamlede empiri. Denne erkendelse af at forskeren selv lægger en diskurs ned over sit materiale er vigtig for at indse, at analyseresultatet selv er et bidrag i den videre debat i samfundet om netværksprojekternes muligheder og barrierer. De identificerede kollektive informationsbehov bliver således selv et indlæg i debatten.

Analyseeksemplet viser hvordan et sammenspil mellem det anvendte teoretiske materiales udsagn og den indsamlede empiri kan drive en forskningsproblematik videre. De to beskrevne teorier udgjorde rammen for den valgte problemstilling, d.v.s. de gav analysen de spørgsmål, der blev stillet til empirien. Den teoretiske ramme kunne dog ikke forudsige svarene på disse spørgsmål. Analysen af empirien gav derfor et resultat, som man kan sige udfordrer den beskrevne teoretiske ramme. Analysen antyder f.eks. at de informationsmæssige betingelser for at netværkene kan etableres ikke altid er opfyldte i dagens netværksprojekter. Den antyder også, at ideen om netværksetableringen eventuelt slet ikke er forankret $\mathrm{i}$ 
hverdagslivets arbejdssammenhænge i det omfang, som man til tider har antaget. Den teoretiske ramme stillede dog også nogle spørgsmål til empirien, som ikke blev besvaret. Til dette kræves yderligere empirisk materiale. Analyseresultaterne viste dog, at der i samfundsdebatten om netværksprojekterne mellem forskning og virksomhed kan eksistere nogle fortolkningsmæssige konflikter. Diskursanalysen kan på denne måde problematisere nogle eksisterende antagelser i samfundet og frem for alt give ophav til nye typer af undersøgelser.

\section{Litteratur}

Beck, U (1997). Risikosamfundet - på vej mod en ny modernitet. Hans Reitzels Forlag.

Byström, K (1997). Municipal Administrators at Work - Information Needs and Seeking in Relation to Task Complexity: A Case-Study amongst Municipal Officials. I: Vakkari, P; Savolainen, R \& Dervin, B (eds) Information Seeking in Context. Taylor Graham, 125-147.

Hersberger, J (2001). Everyday information needs and information sources of homeless parents. The New Review of Information Behavior Research, 119135.

Hjørland, B (1993). Emnereproesentation og informationssøgning. Bidrag til en teori på kundskabsteoretisk grundlag. Göteborgs universitet. Disputas.

Hjørland, B (1996). Informationsbehov - en analyse af et vanskeligt begreb. Bogens Verden nr.4.

Nowotny, H, Scott, P \& Gibbons, M (2001). ReThinking Science. Knowledge and the Public in an Age of Uncertainty. Polity.

Phillips, L (1999). Nærvær på afstand? - den medierede kommunikation af ekspertviden. I: Christrup, Henriette (red) Norvoerskommunikation. Roskilde Universitetsforlag, 109-137.
Potter, J \& Wetherell, M (1987). Discourse and social Psychology. Beyond attitudes and behaviour. London, England: Sage.

Talja, S; Heinisuo, R; P, Luukkainen, S \& Järvelin, K (1997). Discourse Analysis in the development of a Regional Information Service. Beaulieu, M; Davenport, E \& Pors, N O (eds) Library and Information Studies: Research and Professional Practice. Taylor Graham, 109-128.

Talja, S (1997). Constituting "Information" and "User" as research Objects: A Theory of Knowledge Formations as an Alternative to the Information Man -Theory. I: Vakkari, P.; Savolainen, R. \& Dervin, B. (eds) Information seeking in Context. Taylor Graham, 67-80.

Talja, S (1999). Analysing Qualitative Interview Data: The Discourse Analytic Method. Library and Information Science Research, 21 (4), 459-477.

Talja, S; Keso, H \& Pietiläinen, T (1999). The Production of 'context' in information seeking research: a metatheoretical view. Information Processing and Management, 35, 751-763.

Talja, S (2001a). Music, culture, and the library: An analysis of discourses. Lanham, Md.: Scarecow Press.

Talja, S (2001b). Users 'Views of Public Libraries' Social and Cultural Role: A Case Study. Paper from Nordic seminar on Public Library Research, 10-11. dec. 2001. The Royal School of library and Information science, 216-226.

Taylor, R S (1968). Question-Negotiation and Information Seeking in Libraries. College and Research Libraries, May, 178-195.

Taylor, R (1991). Information Use Environments. I: Dervin, B. \& Voigt, M. J. (eds) Progress in Communication Science, Vol.10. Ablex Publishing Corporation, 217-256. 
Tuominen, K \& Savolainen, R (1997). A Social Constructionist Approach to the Study of Information Use as Discursive Action. I: Vakkari, P.; Savolainen, R. \& Dervin, B. (eds) Information Seeking in Context. Taylor Graham, 81-96.

Tuominen, K, Talja, S, og Savoleinen, R (2002). Discourse, Cognition, and Reality: Toward a Social Constructionist Metatheory for Library and Information Science. I: Bruce, H., Fidel, R., Ingwersen, P. og Vakkari, P. (eds) Proceedings of the Fourth Intern. Conference on Conceptions of Library and Information Science, Libraries Unlimited, Greenwood, 271284.
Wetherell, M \& Potter, J (1988). Discourse analysis and the identification of interpretive repertoires. I: Antaki, Charles (ed) Analysing everyday experience: A casebook of methods. London, England: Sage, 168-183.

Wilson, T (1981). On User Studies and Information Needs. Journal of Documentation, 37 (1), 3-15.

Winther Jørgensen, M \& Phillips, L (1999). Diskursanalyse som teori og metode. Samfundslitteratur og Roskilde universitetsforlag.

Trine Schreiber, fil.dr., er lektor ved Institut for Biblioteksudvikling, Danmarks Biblioteksskole, København.ts@db.dk 